\title{
Vitamins as adjunctive treatment for coronavirus disease!
}

\author{
Indu Kapoor*, Hemanshu Prabhakar and Charu Mahajan
}

We read with great interest the article by Li et al., where authors have reviewed many therapeutic strategies for critically ill patients with coronavirus disease (COVID19) [1]. Apart from antiviral drugs and anti-bacterial drugs, authors also discussed various adjunctive interventions which included corticosteroids, thymosin alpha $\mathrm{A}$, cyclosporine A, interferons, gamma globulins and many more. They even discussed the Chinese medicines which were used in past to treat other viral infections. They also stated that these medicines might benefit COVID-19 patients; however, the efficacy and safety of these traditional medicine formulae in COVID-19 need to be further confirmed by clinical trials. Though authors have not mentioned, another important supplementary adjunct to treat these critically ill patients in intensive care unit is various vitamins.

At present times, good immune system is the major weapon against the COVID-19 and vitamins help in efficient functioning of immune system. Inadequacy of these vitamins in the body can lead to suppressed immunity, which may further predisposes the patient towards infection. These vitamins enhance the three level of immunity in body's defence system by supporting physical barriers (skin/mucosa), cellular immunity and antibody production. Vitamins like A, C and E help in enhancing the skin barrier function. Vitamins A, B6, B12, C, D and E work synergistically to support the protective activities of the immune cells. All these vitamins except vitamin C are helpful in antibody production. Vitamin A has been shown to enhance immune response against influenza virus [2]. A controlled human trial has reported that Vitamin $C$ significantly lowers the incidence of pneumonia,

${ }^{*}$ Correspondence: dr.indu.me@gmail.com

AllMS, New delhi, India suggesting that vitamin $\mathrm{C}$ may affect susceptibility to lower respiratory tract infections [3]. Kim et al. in their study indicated that combined use of vitamin $\mathrm{C}$, hydrocortisone, and thiamine (vitamin B1) improves the chest radiologic findings of patients with severe pneumonia and reduce their mortality [4]. Ilie et al. identified a negative association between the mean vitamin $D$ levels in various European countries with COVID-19 cases/1M and COVID-19 mortality [5]. The most vulnerable group, the elderly population, is also the amongst the ones who have the most deficient Vitamin D levels and are at higher risk for COVID-19 infection. A large systematic review and meta-analysis including 11,321 patients has also shown that vitamin $\mathrm{D}$ supplementation is effective against acute respiratory tract infection [6]. Therefore, these vitamins have shown to protect against the acute viral infections and should be the part of adjunctive therapy in critically ill COVID-19 patients. Despite the use of vitamins worldwide in COVID-19 patients, it is diffcult to comment on its absolute therapeutic or preventive role in these group of patients. In future, trials may be needed to understand the role of vitamins in patients of COVID-19.

\section{Authors' contributions}

IK: This author helped in conceptualization of the manuscript and prepared the first draft. HP: This author helped in finalising the manuscript. CM: This author helped in revising the manuscript. All authors read and approved the final manuscript.

\section{Funding}

None.

\section{Competing interests}

The authors declare that they have no competing interests.

Received: 16 June 2020 Accepted: 23 September 2020 Published online: 29 September 2020 


\section{References}

1. Li L, Li R, Wu Z, Yang X, Zhao M, Liu J, Chen D. Therapeutic strategies for critically ill patients with COVID-19. Ann Intensive Care. 2020;10(1):45. https://doi.org/10.1186/s13613-020-00661-z.

2. Patel N, Penkert RR, Jones BG, Sealy RE, Surman SL, Sun Y, Tang L, DeBeauchamp J, Webb A, Richardson J, Heine R, Dallas RH, Ross AC, Webby R, Hurwitz JL. Baseline serum vitamin A and D levels determine benefit of oral vitamin A\&D supplements to humoral immune responses following pediatric influenza vaccination. Viruses. 2019;11(10):907.

3. Hemilä H. Vitamin C intake and susceptibility to pneumonia. Pediatric Infect Dis J. 1997;16(9):836-7.

4. Kim WY, Jo EJ, Eom JS, Mok J, Kim MH, Kim KU, Park HK, Lee MK, Lee K. Combined vitamin C, hydrocortisone, and thiamine therapy for patients with severe pneumonia who were admitted to the intensive care unit: Propensity score-based analysis of a before-after cohort study. J Crit Care. 2018;47:211-8.
5. Ilie PC, Stefanescu S, Smith L. The role of vitamin D in the prevention of coronavirus disease 2019 infection and mortality. Aging ClinExp Res. 2020. https://doi.org/10.1007/s40520-020-01570-8.

6. Martineau AR, Jolliffe DA, Hooper RL, Greenberg L, Aloia JF, Bergman P, Dubnov-Raz G, Esposito S, Ganmaa D, Ginde AA, Goodall EC, Grant CC, Griffiths CJ, Janssens W, Laaksi I, Manaseki-Holland S, Mauger D, Murdoch DR, Neale R, Rees JR, Simpson S, Stelmach I, Kumar GT, Urashima M, Camargo CA. Vitamin D supplementation to prevent acute respiratory tract infections: systematic review and meta-analysis of individual participant data. BMJ. 2017;356:i6583.

\section{Publisher's Note}

Springer Nature remains neutral with regard to jurisdictional claims in published maps and institutional affiliations.

\section{Submit your manuscript to a SpringerOpen ${ }^{\odot}$ journal and benefit from:}

- Convenient online submission

- Rigorous peer review

- Open access: articles freely available online

- High visibility within the field

- Retaining the copyright to your article

Submit your next manuscript at $\boldsymbol{\nabla}$ springeropen.com 